\title{
MEETING THE INDUSTRIAL DEMAND OF CONSTRUCTION ENGINEERING GRADUATE COMPETENCE
}

\author{
Ahmad Rifqi Asrib \\ Universitas Negeri Makassar \\ ahmadrifqi@unm.ac.id \\ Anas Arfandi \\ Universitas Negeri Makassar \\ anas.arfandi@unm.ac.id
}

\begin{abstract}
The aim of this study is to identify the distribution and relevance of graduate competencies in SI PTSP Department FT UNM to those in the world of work. This research was conducted for a year. The location of this research was conducted in according with the distribution of graduates. Samples amount 28 respondents. The data collected used questionnaires, interviews and documentation. The result shows that the waiting period of graduate majoring in engineering education buildings PTSP FT UNM within the last 3 years (2013-2015) in getting a job was an average of 4.4 months. Then, the relevance of the work with their educational background according to their expertise was $85.72 \%$ while $14.28 \%$ are not suitable. Furthermore, the level of relevance of graduates' technical skills in the field of building engineering was at the level of relevant amount $44.48 \%$, and in the field of education at the level of highly relevant amount $55.00 \%$ of the number of observed respondents. The level of employability skills were in the proficient category with the average value about $48.75 \%$ of all aspects.
\end{abstract}

Keywords: graduate competence, the world of work, building engineering, technical skill 


\section{INTRODUCTION}

A country plays important role in human resources investment. It will give economic assets and an increase in the productivity of an individual, family, society and national interests (Gill, Fluitman, \& Dar, 2000; Herschbach \& Gasskov, 2000). One of human resources investments is conducted in form of the development of vocational education. The learning principles in vocational education are prioritizing the importance of suitability of work field demands and the output of education (Arfandi \& Sampebua, 2016).

The competence of the bachelor graduates (S1) in the field of education has been explained in the Descriptor of Human Resources Qualification Level 6 in Indonesian Qualification Framework (IQF), which is the $\mathrm{S} 1$ education program will be resulted are as follow: (1) able to use IPTEK (science and technology) in their expertise and able to adapt in the situation at hand to solve problems; (2) mastering the theoretical concept of certain knowledge in general and the theoretical concept of the specific parts in the knowledge in depth as well as able to formulate solution for procedural problems; (3) able to make a strategic decision based on the analysis of information and data and give direction in selecting various solution alternatives; and (4) responsible for their own work and able to receive responsible for the achievement of organizational working result.

The Department of Civil Engineering Education and Planning (PTSP) manages the study program of Construction Engineering Education (PTB) in the bachelor's degree program (S1). The department of PTSP tries to fulfill the demand of work industry by conducting various efforts. One of the efforts is a tracking study to find out to what extent the relevance of competence owned by the graduates of S1 PTB.

The curriculum at S1 PTB is arranged to fulfill the demand for educators of SMKs (vocational senior high school) in construction engineering expertise package as stated in the formulation of graduate competence profile. The demand for educators in the construction engineering field can be predicted from the number of Public and Private Vocational Senior High Schools (Dardiri, 2011).
Based on the Decree of Directorate General of Secondary Education of the Ministry of Education and Culture No. $7013 / \mathrm{D} / \mathrm{KP} / 2013$ on Expertise Spectrum of Vocational Secondary Education, the expertise needed by the construction engineering expertise package at SMK is steel construction engineering, wood construction engineering, stone and concrete construction technique, and construction drawing technique (Direktur Jenderal Pendidikan Menengah Kementerian Pendidikan dan Kebudayaan, 2013).

The formulation of competence profile of the graduates is made as the performance standard needed to be added in competencebased learning activities describing the vision and mission of the colleges; therefore, it resulted in operational formulation so that the achievement is more focused, measured and observed continually. The research aims to elaborate the relevance of competence of the graduates and their work field from their early graduation to their current work field.

\section{RESEARCH METHOD}

Type of method used was descriptive quantitative. The research was conducted in August-October 2016 at Makassar. However, the respondents could be everywhere. The population of the research was the graduates of S1 study program of the Department of Civil Engineering Education and Planning of the Faculty of Engineering UM for the last three years from 2014 to 2016, which were 113 people. Sampling technique used was proportional where each of the graduate years represents the population. The sample was 28 respondents.

Variables considered in the research were the competence of the graduates of S1 study program of the Department of Civil Engineering Technique Education and Planning, the waiting period of the graduates, the relevance of work field, and the relevance of competence. The operational definitions of each variable were as follow: (1) competence is a set of skills owned by the graduates after completing their study at the program, in this case the technical and employability skills; (2) waiting period is the period between the graduation to the first employment; (3) relevance to work field is the appropriateness of 
the graduates' work field to the knowledge owned, in this case education and civil engineering; and (4) relevance of competence is the appropriateness of the set of knowledge owned by the graduates to the skills needed by the education world and industry/company. Data collection technique used was questionnaire and documentation and descriptive statistics was used as the data analysis technique.

\section{RESULT AND DISCUSSION}

\section{The Distribution of the Graduates of the Study Program of Construction Engineering Education}

The distribution of the graduates was the type of work obtained by the graduates after the last 3 years in the field of consultant, contractor, developer, and teaching or continuing the study to the higher degree of education. Following is the illustration of graduates' distribution (Table 1).

Table 1. The Distribution of Work Field of Graduates for the Last Three Years

\begin{tabular}{cccc}
\hline No & Field Work & Total & Percentage \\
\hline 1 & Consultant & 12 & 43 \\
2 & Contractor & 12 & 43 \\
3 & Developer & - & 0 \\
4 & Education & 4 & 14 \\
\hline & Total & 28 & 100 \\
\hline
\end{tabular}

Based on Table 1 it can be seen that the distribution of the graduates of the study program of Construction Engineering Education was, in average, in the field of consultant and contractor with total 12 people or $43 \%$.

\section{Waiting period of the graduates of the Study Program of Construction Engineering Education}

The waiting period of the graduates is the period between the graduation times to the first employment whether it is relevant or irrelevant to their expertise. However, it is hoped that the first job of the graduates is relevant to their expertise so that the objective of construction engineering education is achieved. The following Table 2 and Table 3 present the waiting period of the graduates based on the job identified.
Table 2. The Waiting Period of Graduates up to Employment

\begin{tabular}{|c|c|c|c|}
\hline No & $\begin{array}{l}\text { Respondent } \\
\text { Code }\end{array}$ & Work Field & $\begin{array}{c}\text { Waiting Period to } \\
\text { work (month) }\end{array}$ \\
\hline 1 & MIH & Consultant & 0 \\
\hline 2 & HSB & Education & 36 \\
\hline 3 & DWA & Education & 36 \\
\hline 4 & TPN & Contractor & 0 \\
\hline 5 & MAA & Consultant & 9 \\
\hline 6 & SLM & Contractor & 0 \\
\hline 7 & ANL & Contractor & 3 \\
\hline 8 & FRD & Consultant & 1 \\
\hline 9 & NGZ & Consultant & 1 \\
\hline 10 & ISP & Consultant & 2 \\
\hline 11 & MYS & Consultant & 2 \\
\hline 12 & MII & Consultant & 0 \\
\hline 13 & BPN & Contractor & 0 \\
\hline 14 & ELM & Consultant & 0 \\
\hline 15 & ARN & Consultant & 2 \\
\hline 16 & МТВ & Contractor & 3 \\
\hline 17 & SFN & Contractor & 6 \\
\hline 18 & AWR & Consultant & 2 \\
\hline 19 & APP & Contractor & 2 \\
\hline 20 & FAY & Education & 0 \\
\hline 21 & NHJ & Education & 0 \\
\hline 22 & GAP & Consultant & 2 \\
\hline 23 & APA & Consultant & 2 \\
\hline 24 & NYK & Contractor & 0 \\
\hline 25 & AWR & Contractor & 4 \\
\hline 26 & TQW & Contractor & 0 \\
\hline 27 & MAD & Consultant & 5 \\
\hline 28 & MAI & Consultant & 5 \\
\hline \multicolumn{3}{|c|}{ Mean } & 4,4 \\
\hline
\end{tabular}

Table 3. The Waiting Period of Graduates to the first Employment based on Work Field

\begin{tabular}{llccc}
\hline No Work Field & Total & $\begin{array}{c}\text { Waiting } \\
\text { Period to } \\
\text { Work } \\
\text { (month) }\end{array}$ & $\begin{array}{c}\text { Mean of } \\
\text { Waiting } \\
\text { Period }\end{array}$ \\
\hline 1 & Consultant & 12 & 31 & 2,58 \\
2 & Contractor & 12 & 20 & 1,66 \\
3 & Developer & - & - & - \\
4 & Education & 4 & 72 & 18 \\
\hline
\end{tabular}


Based on Table 2 and 3, it can be seen that the waiting period for the graduates until their first employment in contractor field was 1.6 month, which was 12 people; consultant was 2.58 months of 4 people; educator was 18 months of 4 people, and the average was 4.4 month of the total sample of 28 people. It can be concluded that the waiting period for the graduate until their first employment was within the fast category.

\section{The Relevance of Work Field of the Graduates of the Study Program of Construction Engineering Education}

Sub-work field identified of the graduates for the last three years were, among other, construction engineer, quality control, calculating work quantity, tools and materials manager of a project, drafter, report administrator, tender documents administrator, calculating $\mathrm{RAB}$, surveyor, field supervisor, laboratory assistant, educators, and so on. However, the graduates were not only working in one field but they could work in various fields simultaneously or alternately. Details about the sub-work field are presented in Table 4.

Table 4. Sub-Work Field of Graduates for the Last Three Years

\begin{tabular}{cl}
\hline No & \multicolumn{1}{c}{ Sub-Work Field } \\
\hline 1 & Construction engineer \\
2 & Quality control \\
3 & Calculate the work quantity \\
4 & Tools and materials manager of a project \\
5 & Workers manager in a project \\
6 & Drafter \\
7 & Report administrator \\
8 & Tender documents administrator \\
9 & Calculating the RAB \\
10 & Surveyor \\
11 & Field supervisor \\
12 & Laboratory assistant \\
13 & Educators \\
\hline
\end{tabular}

Based on Table 4 it can be seen there was good relevance between graduates' work field and their educational background. It can be seen that of the 13 sub-work field items, 24 people worked according to their expertise and only four people worked outside their expertise. The percentage of the relevance of the graduates' work field to their educational background is presented in Table 5 .

In line with the finding of Muhson, Wahyuni, Supriyanto, \& Mulyani (2012), type of the dominant first employment of the graduates of economic education was teacher at the private schools, private employees, teacher/tutor and teacher at the public schools. Based on the type of employment, the relevance level was within the fairly relevant category. It can be seen from the research result where most of the graduates worked in educational field. Referring to the courses taken, it was also relevant since, generally, the alumni teach in the subjects of social sciences, economy and entrepreneurship.

Table 5. The Percentage of Graduates' Work Field

\begin{tabular}{cccc}
\hline No & \multicolumn{1}{c}{ Work Field } & Total Percentage \\
\hline 1 & $\begin{array}{l}\text { In accordance with the } \\
\text { expertise and educational } \\
\text { background }\end{array}$ & 24 & 85,72 \\
2 & $\begin{array}{l}\text { Not in accordance with } \\
\text { the expertise and } \\
\text { educational background }\end{array}$ & 4 & 14,28 \\
\hline \multicolumn{1}{c}{ Total } & 28 & 100,00 \\
\hline
\end{tabular}

\section{The Relevance of Competence of the Graduates of the Study Program of Construction Engineering Education}

As explained above, the graduates of the study program of construction engineering education worked in the consultant, contractor, and education fields. In this case, consultant and contractor were further grouped into civil engineering field since the job descriptions of both fields are similar. The following Table 6 and 7 list the civil engineering field and educational field, respectively.

The role of industry and educational institutions in various developed countries has been well applied. It can be seen from their responsibility to apply the prevailing rules strictly. The role is realized in form of program cooperation, financial support, and research quality improvement. Business world and industry that significantly build cooperation with educational institutions will be given an incentive by the government in form of tax breaks (Mulyono \& Pardjono, 2014). 
The industry and school have limitation in preparing and recruiting quality employees. The schools are limited in financing and managing the study environment according to the working environment while the industry is limited in terms of resources to forming a ready-make workforce when needed. To overcome the gap, both parties should cooperate to build the synergy of input, process, and output to produce quality graduates of SMK (vocational senior high school).

Table 6. The Relevance of Competence of Graduates in Civil Engineering Field

\begin{tabular}{rlrrrr}
\hline No & \multicolumn{1}{c}{ Main Job Descriptions } & MR & \multicolumn{1}{c}{ R } & \multicolumn{1}{c}{ IR } & \multicolumn{1}{c}{ MIR } \\
\hline 1 & Understanding the field / work unit & 42.86 & 57.14 & 0,00 & 0,00 \\
2 & Manual drawing & 39.29 & 42.86 & 10.71 & 7.14 \\
3 & Computer-aided drawing & 53.57 & 39.29 & 7.14 & 0,00 \\
4 & Manual RAB calculation (calculator) & 35.71 & 53.58 & 7.14 & 3.57 \\
5 & Computer-aided RAB calculation & 50.00 & 46.43 & 3.57 & 0,00 \\
6 & Identify Mistakes in RAB calculation & 32.14 & 57.15 & 10.71 & 0,00 \\
7 & Evaluate RAB Feasibility & 35.17 & 50.55 & 14.28 & 0,00 \\
8 & Operating Tools/Machines & 17.86 & 39.28 & 39.29 & 3.57 \\
9 & Maintaining Tools/Machines & 17.86 & 39.83 & 35.17 & 7.14 \\
10 & Fixing the tools/Machines & 10.71 & 32.69 & 35.17 & 21.43 \\
11 & Identify Damage in Tools/Machines & 21.43 & 24.99 & 39.29 & 14.29 \\
12 & Reading the shop drawing & 60.71 & 39.29 & 0,00 & 0,00 \\
13 & Explaining the shop drawing to the builder & 57.14 & 35.72 & 7.14 & 0,00 \\
14 & Conducting/supervising the works according to the schedule & 42.86 & 46.43 & 7.14 & 3.57 \\
15 & Preparing implementation report/ work monitoring & 42.86 & 46.43 & 10.71 & 0.00 \\
16 & Revising jobs mistakes & 39.29 & 53.57 & 3.57 & 3.57 \\
17 & Evaluating job implementation & 35.17 & 46.97 & 14.29 & 3.57 \\
18 & Preparing tender documents & 25.00 & 39.29 & 21.43 & 14.28 \\
19 & Conducting survey & 32.14 & 53.58 & 10.71 & 3.57 \\
\hline & & 36.41 & 44.48 & 16.32 & 7.79 \\
\hline
\end{tabular}

Table 7. The Relevance of Competence of Graduates in Education Field

\begin{tabular}{clcccc}
\hline No & \multicolumn{1}{c}{ Ability } & MR & $\mathrm{R}$ & $\mathrm{IR}$ & $\mathrm{MIR}$ \\
\hline 1 & Understanding the subjects material & 100.00 & 0.00 & 0.00 & 0.00 \\
2 & Preparing learning planning & 100.00 & 0.00 & 0.00 & 0.00 \\
3 & Implementing learning planning & 75.00 & 25.00 & 0.00 & 0.00 \\
4 & Organizing students in the class & 50.00 & 50.00 & 0.00 & 0.00 \\
5 & Learning evaluation & 75.00 & 25.00 & 0.00 & 0.00 \\
6 & Becoming a sample for students & 50.00 & 50.00 & 0.00 & 0.00 \\
7 & Establishing relations among educators & 25.00 & 75.00 & 0.00 & 0.00 \\
8 & Obeying the supervisor's rules & 25.00 & 75.00 & 0.00 & 0.00 \\
9 & Competing the assignments well & 25.00 & 75.00 & 0.00 & 0.00 \\
10 & Conducting regular supervision & 25.00 & 75.00 & 0.00 & 0.00 \\
\hline & $\quad$ Mean & 55.00 & 45.00 & 0.00 & 0.00 \\
\hline
\end{tabular}


Based on Table 6, the average relevance level of technical skills in construction engineering field was in the fairly relevant (R) level with value of $44.48 \%$ and most relevant (MR) of $36.41 \%$. However, there were still irrelevant (IR) skills of $16.32 \%$ and most irrelevant (MIR) of $7.79 \%$.

Based on Table 7, the relevance level of technical skills in educational field was within the category of most relevant (MR) level of $55 \%$ and fairly relevant (R) level of $45.00 \%$. However, there were no irrelevant and very irrelevant skills of the graduates.

The relevance of the graduates' work field to their educational background was within the fairly relevant category. It can be seen from the percentage of the relevance where $85.72 \%$ of the graduates' work field was relevant to the educational background and only $14.28 \%$ was irrelevant. The irrelevant graduates' work fields were financing and honorary staffs as well as those graduates who continued their study to the higher degree of education. In addition, there were also graduates who could not get any job after 2 years of their graduation. Graduates who worked in the irrelevant work field indicated that in addition to their civil engineering skills they also had skills in other fields. However, it is still "a justification" since, according to the objective of vocational education, they should work in their own field because they had learnt the skill but in this case the result obtained did not match.

It should be normatively considered that the graduates will have a changing mind set after completing their study since they have to make money by working in the job available for them. The mindset to work in any field was a proof that they were able to make money for themselves or for their family so they could be independent from their parents and even gave the best for their parents. In addition, it can be stated that the desire to work immediately was a proof that they had the ability to work.

The relevance level of the graduates' technical skills in construction engineering technique was within the fairly relevant level with the value of $37.22 \%$ and very relevant of $36.47 \%$. However, there were also graduates with irrelevant skill of $14.66 \%$ and very irrelevant of $4.51 \%$. For graduates who work- ed as contractor and consultant, generally, they had quite good relevance of competence in technical skill. However, there were also graduates who not yet had good relevance of competence. In addition, the relevance level of technical skill of the graduates in educational level was within the very relevant category with the value of $10.00 \%$ and fairly relevant of $4.29 \%$ and no irrelevant and very irrelevant skills of the graduates.

Although the graduates had gain technical skills during their study, most of them stated that they gained more technical skills at their work. It is a whip for the colleges since they produce less ready to use and ready to work graduates since the working world still needs to give additional skills that are almost half of the skills needed by them. Therefore, learning model at the college should be more oriented to the real working world so the graduates are ready to work in and to be used by the industry.

The study is slightly different to the research by Arfandi, (2013) stated that the graduates of the Diploma III (D3) of civil and construction engineering was dominated by fairly relevant category in terms of the relevance in technical aspect. In addition, in the employability skills aspect only small portions of the graduates were in the category of expert and most of them were in the category of competent.

\section{The Employability Skills of the Graduates of the S1 Program of Construction Engineering Education}

The technical skills of the graduates, as discussed above, were divided into civil engineering and educational fields, whereas there was no division in work field in the employability skill. Details are listed in Table 8 .

In terms of employability skills, the graduates indicated a very good quality with average value amount $35.09 \%$ in Expert category and $48.75 \%$. However, there is less competent amount $12.86 \%$ and needed to developed amount $3.30 \%$ especially in the components of teamwork, problem solving, planning and management, communication, self-management, lifelong learning, and initiative and courage to try skills. 
Table 8 . The employability skills of the graduates

\begin{tabular}{lcccc}
\hline \multicolumn{1}{c}{ Components } & Expert & Competent & $\begin{array}{c}\text { Less } \\
\text { Competent }\end{array}$ & $\begin{array}{c}\text { Need to be } \\
\text { developed }\end{array}$ \\
\hline Communication & 33.21 & 49.29 & 14.64 & 2.86 \\
Teamwork & 34.29 & 52.14 & 9.29 & 4.29 \\
Problem solving & 22.50 & 57.14 & 15.00 & 5.36 \\
Self-management & 39.29 & 46.43 & 12.14 & 2.14 \\
Planning and management & 30.71 & 48.93 & 16.07 & 4.29 \\
Technology & 50.00 & 38.21 & 10.00 & 1.79 \\
Lifelong learning & 40.71 & 45.36 & 11.07 & 2.86 \\
Initiative and courage to try & 30.00 & 52.50 & 14.64 & 2.86 \\
\hline Mean & 35.09 & 48.75 & 12.86 & 3.30 \\
\hline
\end{tabular}

It is a proof that the quality of learning at the college was very low and improvement and development are needed so that graduates, especially in the study program of construction engineering education, could have compatible competence in the working world. The improvement could be in form of the development of a new learning model that bring the students close to the real working world and give them the life skills in order for them to be able to adapt with the working environment, anytime and anywhere.

The implementation of field learning program will give the opportunity for students to apply their knowledge practically and optimize their learning outcomes with additional benefit as their provision to face job market competition. Therefore, the graduates will have the quality and ability to adapt to the change in the working world (Clements \& Cord, 2013). It supported the research of (Laguador \& Ramos, 2014) explained that the leaders in industry are expected the graduates of educational institutions who will work in their company to have the knowledge and skills of analysis, discipline, communication, computer and entrepreneur.

Based on the research of (Dardiri, 2011), PTB study program should grab the needs of the industry especially those related to the competence of the graduates based on their professional field. In addition, graduates should have additional competences in terms of basic attitudes of superior personality, such as, high spirit, achievement motivation, innovative, teamwork, appreciation for differences, honest, and high commitment to work.
A research by Asmawi (2010) stated that to produce good quality graduates, the higher educational institutions should pay attention on (1) the students; prospective students should be well selected so the enrolled students have good quality standard; (2) the educators; lecturers should have qualifications and competences needed for science transformation to the students. The competent and quality educators will facilitate the delivery of knowledge and technology thus the material delivered could be received and developed by the students based on their ability; and (3) facilities and infrastructures; the availability of facilities and infrastructures that support the production of quality graduates. In this case, the educational institutions should cooperate with industry as the absorbers and users of college graduates so that competences are resulted as needed by the industry. Laboratories and workshops are the practice arena for the students thus they need to be equipped with sufficient facilities. In addition, training program should be adjusted to the development and change occurred in the business and working world.

The ASEAN Economic Community (AEC) is a driver for the growing competition in job search. It is not only in the national level but also international. The competition is occurred due to the limited jobs whereas the job seekers are abundant. The existence of AEC demands the government to increase the community's readiness by optimizing the role of vocational education. 


\section{CONCLUSION}

Based on the research result and discussion, conclusions can be drawing as follow:

1. The relevance of the graduates' work field to their education background was appropriate based on the percentage of the graduates' work field that $85.72 \%$ was relevant to the expertise and $14.28 \%$ was irrelevant.

2. The relevance level of technical skills of the graduates in the field of construction engineering was within the fairly relevant level with the value of $44.48 \%$ and in the field of education was in the most relevant level with the value of $55.00 \%$ of the observed respondents, and the employability skills were within the competent category with average value of $48.75 \%$ of all aspects.

Based on the research result, following are some suggestions offered:

1. The relevance of the technical skills that still within the sufficient category and the employability skills of the graduates that within the category of competent require high attention from the management of educational institutions.

2. For other researchers, further studies are needed in the aspects that could improve the technical skills of the students so they could have better competence when they graduate

3. The research recommend for the need of tracking the graduates once in two years to evaluate the performance of the management of educational institutions in producing the graduates.

\section{REFERENCES}

Arfandi, A. (2013). Relevansi kompetensi lulusan Diploma Tiga teknik sipil di dunia kerja. Jurnal Pendidikan Vokasi, 3(3), 283-292. Retrieved from https://journal.uny.ac.id/index.php/jpv/ar ticle/view/1843

Arfandi, A., \& Sampebua, O. (2016). Kesiapan pelaksanaan praktik kerja industri Program Studi Keahlian Teknik Bangunan di Kota Makassar. Jurnal Cakrawala Pendidikan, 1(1). https://doi.org/10.21831/cp.v1i1.8368
Asmawi, M. R. (2005). Strategi meningkatkan lulusan bermutu di perguruan tinggi. Makara Hubs-Asia (Human Behavior Studies in Asia), 8(3). Retrieved from http://hubsasia.ui.ac.id/index.php/hubsas ia/article/view/124

Clements, M. D., \& Cord, B. A. (2013). Assessment guiding learning: developing graduate qualities in an experiential learning programme. Assessment \& Evaluation in Higher Education, 38(1), 114-124. https://doi.org/10.1080/02602938.2011.6 09314

Dardiri, A. (2011). Diversifikasi kompetensi lulusan pendidikan dan latihan vokasi untuk lebih kompetitif. Teknologi Dan Kejuruan, 34(1). Retrieved from http://journal.um.ac.id/index.php/teknolo gi-kejuruan/article/view/3023

Direktur Jenderal Pendidikan Menengah Kementerian Pendidikan dan Kebudayaan. Surat Keputusan tentang Spektrum Pendidikan SMK, Pub. L. No. 7013/D/KP/2013 (2013). Indonesia.

Gill, I. S., Fluitman, F., \& Dar, A. (2000). Vocational education and training reform: Matching skills to markets and budgets. ERIC. Retrieved from http://documents.worldbank.org/curated/ en/306571468750301579/pdf/multipage.pdf

Herschbach, D. R., \& Gasskov, V. (2000). Financing workforce preparation programs. In D. R. Hershbach \& C. P. Campbell (Eds.), Workforce preparation: an international perspective (pp. 74-88). Ann Arbor, Michigan: Prakken Publications.

Laguador, J. M., \& Ramos, L. R. (2014). Industry-partners' preferences for graduates: Input on curriculum development. Journal of Education and Literature, 1(1), 1-8. Retrieved from http://www.rassweb.org/journal/5/resear ch_paper/152.html

Muhson, A., Wahyuni, D., Supriyanto, S., \& Mulyani, E. (2012). Analisis relevansi lulusan perguruan tinggi dengan dunia kerja. Jurnal Economia, 8(1), 42-52. Retrieved from 
https://journal.uny.ac.id/index.php/econo $\mathrm{mia} /$ article/view/800

Mulyono, W. D., \& Pardjono, P. (2014).

Peran komite sekolah dalam

penyelenggaraan pendidikan SMK di
Kabupaten Lamongan, Jawa Timur. Jurnal Pendidikan Vokasi, 4(3).

Retrieved from

https://journal.uny.ac.id/index.php/jpv/ar ticle/view/2562 